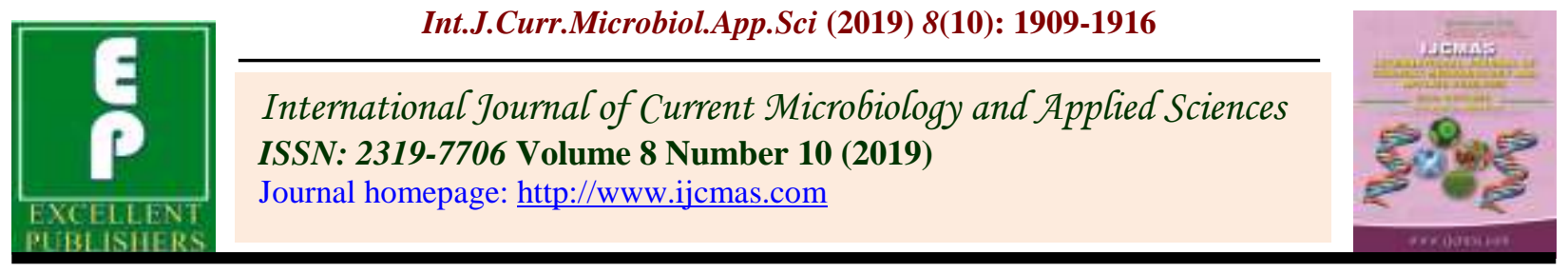

Original Research Article

https://doi.org/10.20546/ijcmas.2019.810.222

\title{
Production and Economic Feasibility of Chickpea (Cicer arietinum. L.) in Mustard (Brassica juncea) Intercropping System under Different Row Ratio for Northern Dry Zone of Karnataka
}

\author{
Ramarao $^{1 *}$ and H.T. Chandranath ${ }^{2}$ \\ Department of Agronomy, University of Agricultural Sciences, \\ Dharwad -580 005 Karnataka, India \\ *Corresponding author
}

\begin{tabular}{|l|}
\hline Ke y w o r d s \\
Chickpea, Mustard, \\
Intercropping, Row \\
ratio, Production
\end{tabular}

A B S T R A C T

\section{Introduction}

One of the challenging tasks for this century $\left(21^{\text {st }}\right)$ is to produce the food, fodder, fuel and fiber for every day needs of the human beings. Agriculture land is declining day by day as it is used for non-agricultural purposes. It is rather predictable to accommodate production in accessible crops/cropping systems. It is estimated that India's population will reach nearly 1350 million by $2020 \mathrm{AD}$. The food requirement of the country by $2020 \mathrm{AD}$ is anticipated to be around 256 million tonnes (Paroda and Kumar, 2000). This supplementary food production has to come from present land of cultivated area $(143.2 \mathrm{~m}$ ha) and water resources. Thus in the absence of possibilities for horizontal expansion of land, vertical growth of these crops through intercropping with suitable crops having higher yield potential offering varying competition in spatial and temporal dimension is the need of time. Time and space exploitation in agriculture through intercropping is one of the options available for increasing the production per unit land area (Sankaran and Rangasamy, 1990). 
India stands first in area and production of both oilseeds and pulses, but still we are finding huge gap between demand and supply of both the crops. The total demand for oilseeds is increasing continuously as a result of increasing population growth which might be due to low productivity of these oilseeds. In India, pulses are grown annually on an area of about 24.91 million hectares with a production of 16.34 million tonnes with average productivity of $656 \mathrm{~kg}$ per hectare (Anon., 2017). By 2030, pulse requirement in the country is projected at 32 million tonnes and as per ICMR recommendations we need to have $80 \mathrm{~g}$ of pulses and $38 \mathrm{~g}$ of oilseeds in our daily food as against the present intake of only $48 \mathrm{~g}$ of pulses and $18.3 \mathrm{~g}$ of oilseeds (Anon., 2017a). The shortage of pulse and oilseeds has aggravated the problem of malnutrition. So this gap has to be bridged by crop intensification by means of intercropping.

Intercropping is growing of two or more crops simultaneously on the same piece of land with a definite row proportion (Reddy and Reddy, 2007). Many of the tropical and subtropical countries are well versed with significance of intercropping as it helps in better utilization of resources like soil moisture, nutrients, space and light both above and below ground resources. The usual practice consists of growing pulses or oilseeds as a component crop in the mixtures of food grain crops and there is little scope to bring additional area under these crops (pulses and oilseeds) due to stiff competition from cereals, shrinkage of land holding and use of land for urbanization etc. Thus, in the absence of possibilities for horizontal expansion, the vertical growth of these crops through intercropping with suitable crops having higher yield potential offering varying competition in spatial and temporal dimension is the need of time. Chickpea is traditionally grown as a mixed crop with several crops like sorghum, mustard, linseed, barley, spices etc. without taking into consideration of spatial row arrangement. Consequently, crop suffers to a great extent and hence yields are reduced. Spatial arrangements in intercropping have important effect on the balance of competition between the component crops and their productivity (Pandhi and Panigarahi, 2006). Mustard is taller plant with broader crop canopy shows the greater competing ability than chickpea accommodating more rows of mustard in between the chickpea cause shading effect which affect the photosynthesis ultimately hamper growth and yield of chickpea (Lal et $a l ., 2000)$. Therefore judging appropriate row arrangement in such a way that, a tall plant for high light intensities at top and a compact chickpea for lower intensities at bottom without much shading effect can lead to efficient use of light as in multi-storey cropping for higher yields. In Northern Dry Zone (zone-3) of Karnataka, chickpea, wheat and safflower are the predominant crops during rabi season. Research information is available on cereal + legume intercropping but not on legume + oilseed system viz., chickpea and mustard intercropping is lacking in this zone. In order to increase the diversity and also to introduce a new cropping system in this region, mustard as a component crop in chickpea based intercropping system looks to be advantageous. Keeping these facts in view, a field experiment was conducted at Main Agricultural Research Station, Dharwad, during rabi 2017.

\section{Materials and Methods}

The experiment was conducted at Main Agricultural Research Station, UAS, Dharwad during the rabi season of 2017. The soil was clayey having initial soil $\mathrm{pH}$ of 7.3 and organic carbon $0.53 \%$ and available $\mathrm{N}, \mathrm{P}$ and $\mathrm{K}$ of 253,30 and $320 \mathrm{~kg} \mathrm{ha}^{-1}$ respectively. The field was prepared by employing one deep ploughing and harrowing. The average rainfall of area was $722.7 \mathrm{~mm}$ but during 2017 a 
rainfall of $582.8 \mathrm{~mm}$ was received. The experiment was laid out in randomized complete block design with 3 replications. There were ten treatments consisting of sole crops of chickpea and mustard \& chickpea + mustard intercropping in different row ratios $2: 1,3: 1,3: 3,4: 2,4: 4,5: 1,6: 2$ and 8:2. A row spacing of $30 \mathrm{~cm}$ was adopted to both the crops with plant to plant spacing of $10 \mathrm{~cm}$. Common fertilizer dose of 25:50:0 (N: $\left.\mathrm{P}_{2} \mathrm{O}_{5}: \mathrm{K}_{2} \mathrm{O} \mathrm{kg} \mathrm{ha}{ }^{-1}\right)$ and 60:50:0 $\left(\mathrm{N}: \mathrm{P}_{2} \mathrm{O}_{5}: \mathrm{K}_{2} \mathrm{O}\right.$ $\mathrm{kg} \mathrm{ha-1}$ ) for mustard was applied based on population in each treatment. The cultivar used were Jaki-9218 (chickpea) and NRCHB101 (mustard) with seed rate of $62.5 \mathrm{~kg} \mathrm{ha}^{-1}$ (chickpea) and $5.0 \mathrm{~kg} \mathrm{ha}^{-1}$ (mustard). The crops were sown on $19^{\text {th }}$ cotober 2017 and harevsted on $2^{\text {nd }}$ february 2018. Crops were raised under protective irrigation. Chickpea was protected with chlorantrainiprole against pod borer (Helicoverpa armigera) during floweing and pod formation stage and mustard was sheltered aginst white rust with spray of ridomil gold during flowering stage. For recording of biometrical observations randomly five plants were taken from net plots excluding border rows. These samples were dried at $70{ }^{\circ} \mathrm{C}$ to attain constant dry weight. The dry matter production per plant was expressed as gram per plant. The data recorded on various parameters subjected to Fisher's method of analysis of variance and interpretation of the data as given by Gomez and Gomez (1984). The level of significance used in ' $\mathrm{F}$ ' and ' $\mathrm{t}$ ' test was $\mathrm{P}=0.05$. Critical difference $(C D)$ values were calculated where the ' $F$ ' test was found significant.

\section{Results and Discussion}

\section{Chickpea growth, yield attributes}

Higher plant height was recorded with sole chickpea at 30,60 DAS and at harvest (Table 1). This was due to higher vegetative growth of sole chickpea. Among the intercropping treatments, 8:2 row ratio recorded higher plant height at 30,60 DAS and at harvest. The increase in plant height was up to an extent of 9.51 and 11.43 per cent at $60 \mathrm{DAS}$ and at harvest respectively. Yadav et al., (2013) also reported the similar results in chickpea + mustard intercropping system.

Higher leaf area and leaf area index were recorded with sole chickpea at 30,60 DAS and at harvest (Table 1). This might be due to higher population per unit area and vegetative growth of sole chickpea. The increase in leaf area index was to an extent 5.49, 10.93 and 10.28 per cent at 30,60 DAS and at harvest, respectively over 8:2 row ratio of chickpea + mustard. This might be due to maximum plant population, sunlight was used more efficiently than other intercropping treatments due to dense leaf foliage of single crop, absence of inter pace competition and limited disturbance of habitat. These results corroborate the results of Vinaykant (2005). Among the intercropping, higher leaf area was recorded with 8:2 row ratio of chickpea + mustard 30 $\left(3.50 \mathrm{dm}^{2}\right.$ plant $\left.^{-1}\right)$ at 60 DAS $\left(8.80 \mathrm{dm}^{2}\right.$ plant $^{-}$ $\left.{ }^{1}\right)$ and at harvest $\left(9.18 \mathrm{dm}^{2}\right.$ plant $\left.^{-1}\right)$. Higher leaf area index was recorded with 8:2 row ratio at $30(0.91), 60$ DAS (1.10) and at harvest (1.07) over 6:2 row ratio of chickpea + mustard. The increase in leaf area index was up to an extent $15.18,14$ and 15.05 per cent at 30,60 DAS and at harvest respectively, over $6: 2$ row ratio of chickpea + mustard. This might be due to less intra crop competition for light, moisture and nutrients. These results are similar with the findings of Singh and Rathi (2006).

Higher numbers of primary branches were recorded with sole chickpea (5.7) (Table 1). The increase in number of primary branches to the tune of 2.8, 3.6 and 10.94 per cent at 30, 60 DAS and at harvest respectively over 8:2 row ratio of chickpea + mustard. This might be due to higher vegetative growth of the sole 
chickpea which resulted in higher primary branches in sole chickpea. Among the intercropping treatments, 8:2 row ratio of chickpea + mustard recorded higher number of primary branches at 30,60 DAS and at harvest (Table 1). Total dry matter production was found higher with sole chickpea at 30,60 DAS and at harvest $(3.80,15.14$ and $24.70 \mathrm{~g}$ plant $^{-1}$, respectively) (Table 2; Fig. 1). This might be due to higher plant height which was due to increased population, leaf area, leaf area index, number of branches, higher photosynthesis and higher intercepted radiation. Vyas et al., (1991) reported the similar results with chickpea + mustard intercropping system. With respect to different row ratios of chickpea and mustard, 8:2 row ratio of chickpea + mustard recorded higher dry matter production at 30 (3.60 g plant $\left.^{-1}\right), 60$ DAS (13.91 g plant $\left.{ }^{-1}\right)$ and at harvest $(22.70 \mathrm{~g}$ plant $\left.^{-1}\right)$. The increase in the dry matter was up to an extent of 16.12, 3.42 and 3.60 per cent at 30,60 DAS at harvest respectively, over 6:2 row ratio of chickpea + mustard. This was due to more number of branches, less cropcompetition for space, nutrient and moisture and higher quantity of solar radiation consequently produced more dry matter. These results are similar with the findings of Tigga et al., (2004), Varshney and Arya (2004) who also stated that higher dry matter production was due to higher plant height, higher dry weight of nodules in chickpea + mustard intercropping system.

\section{Yield attributes and yield of chickpea}

Sole chickpea (Table 2) recorded significantly higher grain and haulm yield (1,749 and 1,969 $\mathrm{kg} \mathrm{ha}{ }^{-1}$, respectively) over all other intercropping treatments. The higher grain yield with sole chickpea was mainly attributed to higher plant population per unit area, better nodule formation, no competition from intercrop, less disturbance of habitat, less inter space competition of chickpea and also due to higher yield attributes viz., pods per plant, seeds per pod and test weight. These results are in conformity with findings of Tripathi $e t$ al., (2005), Manjithkumar (2009), Alam. (2015) who also stated that higher yield with sole chickpea was mainly due to the higher population per unit area and less disturbance to the microclimate of the chickpea. Among the intercropping treatments, higher grain and haulm yield of chickpea was recorded with 8:2 row ratio of chickpea + mustard $\left(1,610 \mathrm{~kg} \mathrm{ha}^{-1}\right.$ and 1,890 $\mathrm{kg} \mathrm{ha}^{-1}$ respectively) (Table 2).

The increase with grain and straw yield of sole chickpea to an extent of 9.74 and 5.40 per cent, respectively over 6:2 row ratio of chickpea + mustard. This was mainly due to higher population of chickpea per unit area, lesser competition of mustard on chickpea, higher pods per plant, seeds per pod and test weight. The higher haulm yield at 8:2 row ratio of chickpea + mustard was mainly due to increase in plant height, leaf area, leaf area index which led to efficient transformation of photosynthates from source to sink, total number of branches and total dry matter production. These results are similar with the findings of Alam (2015) and Thakur et al., (2000) who also stated that higher haulm yield was due to higher population and total dry matter production per unit area of chickpea.

There was no much difference with respect to harvest index of sole chickpea. However, numerically higher harvest index was recorded with sole chickpea (46.6\%). This was mainly due to higher grain and haulm yield of chickpea possibly due to better growth, increased number of pods per plant, seeds per pods and increased plant density per unit area as compared to other intercropping treatments. Similar results were found by Manjitkumar (2009), Kumar and Nandan (2007), Tripathi et al., (2005) and Ahlawat et al., (2005) in chickpea and mustard intercropping system. 
Table.1 Growth, yield attribute and yield of chickpea as influenced by different row ratio of chickpea and mustard intercropping

\begin{tabular}{|c|c|c|c|c|c|c|c|c|c|c|c|c|c|}
\hline \multirow{2}{*}{\multicolumn{2}{|c|}{ Treatments }} & \multirow{2}{*}{\multicolumn{3}{|c|}{ Plant height $(\mathbf{c m})$}} & \multirow{2}{*}{\multicolumn{3}{|c|}{ Leaf area $\left(\mathrm{dm}^{2}\right.$ plant $\left.^{-1}\right)$}} & \multirow{2}{*}{\multicolumn{3}{|c|}{ Leaf area index }} & \multirow{2}{*}{\multicolumn{3}{|c|}{ No. of primary branches per plant }} \\
\hline & & & & & & & & & & & & & \\
\hline & & \multirow{2}{*}{$\begin{array}{c}\text { 30 DAS } \\
19.1\end{array}$} & \multirow{2}{*}{\begin{tabular}{|c|} 
60 DAS \\
31.2 \\
\end{tabular}} & \multirow{2}{*}{$\begin{array}{c}\text { At harvest } \\
33.5\end{array}$} & \multirow{2}{*}{$\begin{array}{c}\text { 30 } \\
\text { DAS } \\
1.43\end{array}$} & \multirow{2}{*}{$\begin{array}{c}\mathbf{6 0} \\
\text { DAS } \\
2.50\end{array}$} & \multirow{2}{*}{$\begin{array}{c}\text { 90 } \\
\text { DAS } \\
2.45\end{array}$} & \multirow{2}{*}{$\begin{array}{c}\text { 30 } \\
\text { DAS } \\
0.48\end{array}$} & \multirow{2}{*}{$\begin{array}{c}\mathbf{6 0} \\
\text { DAS } \\
0.83\end{array}$} & \multirow{2}{*}{$\begin{array}{c}\text { 90 } \\
\text { DAS } \\
0.82\end{array}$} & \multirow{2}{*}{\begin{tabular}{|c|}
30 DAS \\
2.7 \\
\end{tabular}} & \multirow{2}{*}{$\begin{array}{c}\text { 60 DAS } \\
4.1\end{array}$} & \multirow{2}{*}{$\begin{array}{c}\text { At harvest } \\
4.2\end{array}$} \\
\hline $\mathbf{T}_{1}$ & Chickpea + mustard (2:1) & & & & & & & & & & & & \\
\hline $\mathbf{T}_{2}$ & Chickpea + mustard (3:1) & 19.4 & 32.0 & 33.7 & 1.50 & 2.65 & 2.50 & 0.50 & 0.88 & 0.83 & 2.8 & 4.2 & 4.4 \\
\hline $\mathbf{T}_{3}$ & Chickpea + mustard (3:3) & 18.3 & 29.4 & 31.8 & 1.30 & 2.36 & 2.24 & 0.43 & 0.79 & 0.75 & 2.2 & 3.9 & 4.1 \\
\hline $\mathbf{T}_{4}$ & Chickpea + mustard (4:2) & 19.8 & 33.3 & 35.7 & 1.81 & 2.90 & 2.55 & 0.60 & 0.90 & 0.85 & 2.5 & 4.3 & 4.3 \\
\hline $\mathbf{T}_{5}$ & Chickpea + mustard (4:4) & 18.8 & 29.8 & 32.6 & 1.40 & 2.43 & 2.40 & 0.47 & 0.81 & 0.80 & 2.6 & 4.0 & 4.2 \\
\hline $\mathbf{T}_{6}$ & Chickpea + mustard $(5: 1)$ & 20.1 & 34.9 & 35.4 & 1.93 & 3.0 & 2.62 & 0.64 & 0.92 & 0.87 & 2.9 & 4.4 & 4.5 \\
\hline $\mathbf{T}_{7}$ & Chickpea + mustard $(6: 2)$ & 20.8 & 35.2 & 35.6 & 2.36 & 3.12 & 2.90 & 0.79 & 0.96 & 0.93 & 3.1 & 4.8 & 4.9 \\
\hline $\mathbf{T}_{8}$ & Chickpea + mustard $(8: 2)$ & 21.2 & 38.5 & 39.6 & 2.74 & 3.43 & 3.21 & 0.91 & 1.10 & 1.07 & 3.2 & 5.0 & 5.2 \\
\hline \multirow[t]{3}{*}{$\mathbf{T}_{9}$} & Sole chickpea & 22.0 & 43.3 & 44.5 & 2.89 & 3.83 & 3.55 & 0.96 & 1.28 & 1.18 & 3.2 & 5.3 & 5.7 \\
\hline & S.Em \pm & 0.85 & 1.52 & 1.40 & 0.07 & 0.12 & 0.20 & 0.02 & 0.04 & 0.06 & 0.24 & 0.18 & 0.19 \\
\hline & CD $(P=0.05)$ & NS & 4.56 & 4.20 & 0.21 & 0.36 & 0.60 & 0.07 & 0.12 & 0.18 & NS & 0.54 & 0.57 \\
\hline
\end{tabular}

Table.2 Dry matter production, yield and economics of chickpea as influenced by different row ratios of chickpea and mustard intercropping system

\begin{tabular}{|c|c|c|c|c|c|c|c|c|c|c|}
\hline \multicolumn{2}{|r|}{ Treatments } & \multicolumn{3}{|c|}{ TDMP $\left(g_{\text {plant }}^{-1}\right)$} & \multicolumn{2}{|c|}{ Yield $\left(\mathrm{kg} \mathrm{ha}^{-1}\right)$} & \multirow{3}{*}{$\begin{array}{c}\text { HI (\%) } \\
41.2\end{array}$} & \multirow{3}{*}{ 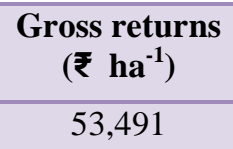 } & \multirow{3}{*}{$\begin{array}{c}\begin{array}{c}\text { Net returns } \\
\left(₹ \text { ha }^{-\mathbf{1}}\right)\end{array} \\
21,373 \\
\end{array}$} & \multirow{3}{*}{$\begin{array}{l}\text { B: } \mathrm{C} \\
\text { ratio } \\
1.67\end{array}$} \\
\hline & & \multirow{2}{*}{$\begin{array}{c}30 \text { DAS } \\
2.55\end{array}$} & \multirow{2}{*}{$\begin{array}{c}\text { 60 DAS } \\
11.95\end{array}$} & \multirow{2}{*}{$\begin{array}{c}\text { AH } \\
19.50\end{array}$} & \multirow{2}{*}{$\begin{array}{c}\text { Grain } \\
452\end{array}$} & \multirow{2}{*}{$\begin{array}{c}\text { Haulm } \\
650\end{array}$} & & & & \\
\hline $\mathbf{T}_{1}$ & Chickpea + mustard $(2: 1)$ & & & & & & & & & \\
\hline $\mathbf{T}_{2}$ & Chickpea + mustard $(3: 1)$ & 2.80 & 12.14 & 19.80 & 611 & 810 & 43.0 & 58,293 & 25,942 & 1.80 \\
\hline $\mathbf{T}_{3}$ & Chickpea + mustard $(3: 3)$ & 2.28 & 11.46 & 18.72 & 384 & 552 & 41.1 & 58,801 & 27,205 & 1.86 \\
\hline $\mathbf{T}_{4}$ & Chickpea + mustard $(4: 2)$ & 2.90 & 12.38 & 20.20 & 684 & 944 & 42.3 & 61,744 & 29,629 & 1.92 \\
\hline $\mathbf{T}_{5}$ & Chickpea + mustard (4:4) & 2.43 & 11.65 & 19.0 & 418 & 627 & 40.0 & 62,528 & 30,933 & 1.98 \\
\hline$T_{6}$ & Chickpea + mustard $(5: 1)$ & 3.00 & 13.36 & 21.80 & 961 & 1,223 & 44.4 & 67,617 & 35,053 & 2.08 \\
\hline $\mathbf{T}_{7}$ & Chickpea + mustard $(6: 2)$ & 3.10 & 13.45 & 21.94 & 1,467 & 1,793 & 45.0 & 82,697 & 51,346 & 2.64 \\
\hline $\mathbf{T}_{8}$ & Chickpea + mustard $(8: 2)$ & 3.60 & 13.91 & 22.70 & 1,610 & 1,890 & 46.0 & 86,091 & 53,706 & 2.66 \\
\hline \multirow[t]{3}{*}{$\mathbf{T}_{9}$} & Sole chickpea & 3.80 & 15.14 & 24.70 & 1,749 & 1,969 & 46.5 & 77,291 & 44,154 & 2.33 \\
\hline & S.Em \pm & 0.18 & 0.48 & 0.77 & 37 & 51.8 & 2.1 & 76171 & 39,887 & 2.10 \\
\hline & $\mathrm{CD}(\mathrm{P}=\mathbf{0 . 0 5})$ & 0.54 & 1.44 & 2.33 & 113 & 155.4 & NS & 2292 & 2227 & 0.06 \\
\hline
\end{tabular}

Note: DAS- days after sowing, TDMP- total dry matter production, AH- after harvest, HI-Harvest index 

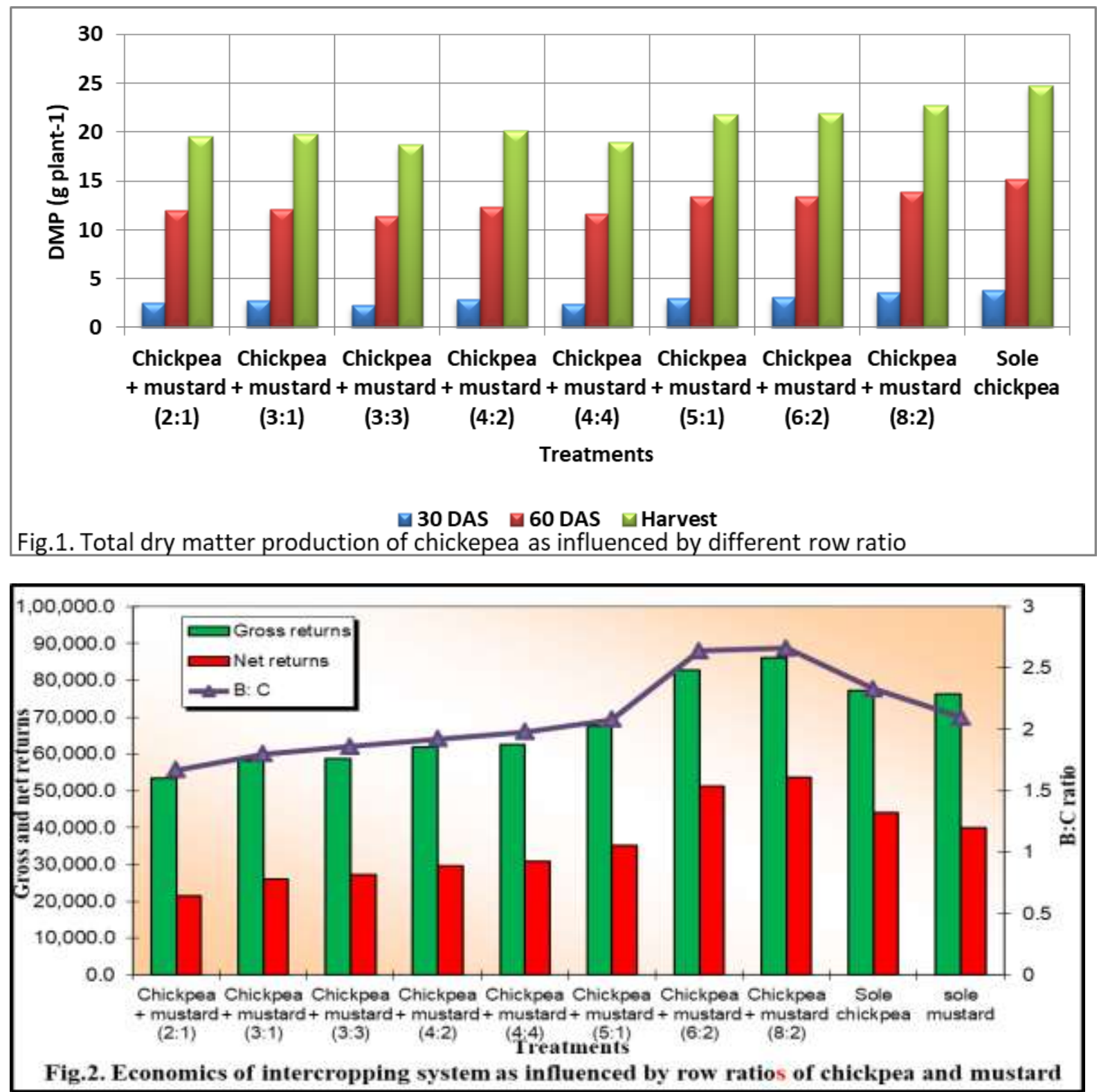

\section{Economics of the intercropping system}

Chickpea + mustard with 8:2 row ratio gave higher gross returns $\left(₹ 86,091 \mathrm{ha}^{-1}\right.$ ) and was on par with chickpea + mustard with 6:2 row ratio ( $₹ 82,697 \mathrm{ha}^{-1}$ ), followed by chickpea + mustard with 5:1, 4:4 and 4:2 row ratios ( $₹$ $67,617,62,528$ and $61,744 \mathrm{ha}^{-1}$ respectively). The lowest gross returns were recorded with $2: 1$ row ratio of chickpea + mustard ( $₹$ $53,491 \mathrm{ha}^{-1}$ ) (Fig. 2). The increased gross returns in intercropping system were mainly due to higher chickpea equivalent yield.
Net returns $\left(₹ 53,706 \mathrm{ha}^{-1}\right.$ ) were found higher with chickpea + mustard at 8:2 row proportion and was found on par with 6:2 row ratio of chickpea + mustard ( $₹ 51,346 \mathrm{ha}^{-1}$ ) followed by sole chickpea ( $₹ 44,154 \mathrm{ha}^{-1}$ ) and sole mustard ( $₹ 39,887 \mathrm{ha}^{-1}$ ). The lowest net returns ( $₹ 21,373 \mathrm{ha}^{-1}$ ) were recorded with 2:1 row ratio of chickpea + mustard. The higher gross and net returns with chickpea + mustard intercropping system was mainly due to higher economic yield and better price structure for chickpea and mustard. 
Guruvindersingh (2005) also observed higher gross returns ( $₹ 43,248 \mathrm{ha}^{-1}$ ) and net returns $\left(₹ 10,092 \mathrm{ha}^{-1}\right.$ ) with $6: 2$ row ratio of chickpea + mustard intercropping system.

Among the intercropping treatments, higher benefit cost ratio was observed with chickpea + mustard with 8:2 row ratio (2.66) and was on par with $6: 2$ row ratio of chickpea + mustard (2.64) and followed by sole chickpea (2.33), sole mustard (2.10) and 5:1 row ratio of chickpea + mustard (2.08), which might be attributed to higher returns in these treatments and lower cost of cultivation. The lowest B: C ratio was recorded with 2:1 row ratio of chickpea + mustard (1.67).

From the above study it can be concluded that, intercropping of chickpea + mustard at $8: 2$ row ratio was found to be more productive and profitable chickpea intercropping system as it recorded yield, higher net returns and benefit cost ratio compared to other intercropping treatments and 6:2 row ratio of chickpea + mustard also recorded all economic parameters over other intercropping treatments.

\section{Acknowledgments}

The study was funded Department of Agronomy, UAS, Dharwad for their valuable input and contributions to the research.

\section{References}

Ahlawat I P S, Gangaiah B. and Singh. O. 2005. Production potential of chickpea (Cicer arietinum) based intercropping systems under irrigated conditions. Indian J. Agron., 50 (1): 27-30.

Alam M I. 2015. Intercropping efficiency of chickpea (Cicer arietinum) based intercropping system under rainfed condition of Bihar. Ann. Agric. Res., 36 (4): 370-376.
Anonymous 2017a. Area, production and productivity of chickpea and mustard in India and Karnataka. $w w w$. Indiastat.com.

Anonymous 2017b, Annu. Rep. 2016-17. Department of Agriculture, Cooperation \& Farmers Welfare, p. 137.

Gomez K A. and Gomez A. A. 1984. Statistical procedures for agricultural research. edn 2, John Willey, New York, p. 693.

Gurvindersingh. 2005, Intercropping of mustard with chickpea. M.Sc. Thesis. G.B. Pant Univ. Agric. Tech. Pantnagar (India).

Kumar G. and Nandan R. 2007. Effect of date and pattern of planning on productivity and economics of chickpea + mustard intercropping system. J. Food Leg., 20 92): 184-186.

Lal R B, Verma A K, and Ahuja K N. 2000. Intercropping of oilseed and pulses crops in wheat (Triticum aestivum) under fertilizer and water constraint situations. Indian J. Agron., 43(2): 253255.

Manjithkumar 2009. Influence of different row proportions on yield components and yield of rabi crops under different intercropping systems. M. Sc. Thesis, Univ. Agric. Sci. Dhawad (India).

Pandhi A K. and Panigarahi R. K. 2006. Effect of inter cropping and crop geometry on productivity, economics, energetic and soil fertility status of Maize based intercropping system. Indian J. Agron., 51 (3): 174-177.

Paroda R S. and Kumar P. 2000. Food production and demand in South Asia. Agril. Econ. Res. Rev. 13 (1):1-24.

Reddy R T. and Reddy S G H. 2007. Principles of Agronomy, Kalyani Publishers, Ludhiana (India).

Sankaran S. and Rangasamy A. 1999. Farming system research in agronomic research towards sustainable 
agriculture, Indian Society of Agronomy, Division of Agronomy, IARI, New Delhi, pp. 69-80.

Singh K K. and Rathi K S. 2003. Dry matter production and productivity as influenced by staggered sowing of mustard intercropped at different row ratios with chickpea. J. Agron. Crop Sci., 189 (1): 169-175.

Thakur N S, Pannase S K. and Sharma R S. 1998. Production potential of gram based intercropping systems under rainfed condition. Indian J. Agron., 45 (3): 534-39

Tripathi H N. Chand S. and Tripathi A K. 2005. Biological and economical feasibility of chickpea and Indian mustard cropping system under varying levels of phosphorous. Indian J. Agron., 50 (1): 31-34.

Varshney J G. and Arya R L. 2004. Effect of integrated nutrients use and weed control methods on sole gram and gram + Indian mustard inter cropping system. Indian J. Agric. Sci., 74(3): 121-125.

Vinaykant, 2005. Effect of different row ratios of chickpea and mustard on productivity and economics in intercropping system under dry land conditions. M. Sc. Thesis. CCSAU \&T, Haryana (India).

Vyas A K and Rai R K. 1993. Effect of planting patterns and phosphorus levels on phosphorus uptake and yield of mustard and chickpea under rainfed conditions. Fertilizer News., 38 (2): 4349.

Yadav P K., Singh A P. and Ram R. 2013. Effect of row ratio and phosphorus fertilizer in chickpea and mustard intercropping system. Indian $J$. Agronomy, 58(2): 198-202.

\section{How to cite this article:}

Ramarao and Chandranath, H.T. 2019. Production and Economic Feasibility of Chickpea (Cicer arietinum. L.) in Mustard (Brassica juncea) Intercropping System under Different Row Ratio for Northern Dry Zone of Karnataka. Int.J.Curr.Microbiol.App.Sci. 8(10): 1909-1916. doi: https://doi.org/10.20546/ijcmas.2019.810.222 